\title{
Analysis of Motivations of Foreign Tourists Behind Their Choice of Turkish Cuisine Based on Their Neophobic and Neophilic Tendencies: A Research in Istanbul*
}

\section{Yabancı Turistlerin Türk Mutfağı Seçim Motivasyonlarının Neofobi ve Neofili Eğilimlerine Göre İncelenmesi: İstanbul'da Bir Araştırma}

\author{
Dr. Öğr. Üyesi Meral ÜZÜLMEZ \\ Osmaniye Korkut Ata Üniversitesi \\ Kadirli Uygulamalı Bilimler Yüksekokulu \\ Osmaniye, Türkiye \\ E-posta: meraluzulmez@osmaniye.edu.tr
}

\author{
Doç. Dr. Gürkan AKDAĞ \\ Mersin Üniversitesi \\ Turizm Fakültesi \\ Mersin/Türkiye \\ E-posta: gurkanakdag@mersin.edu.tr
}

\begin{abstract}
This study seeks to determine the impact of the neophobic and neophilic tendencies of foreign tourists on motivations behind their choice of Turkish cuisine. The population of this study consists of foreign tourists visiting Istanbul in 2018. In this study designed at an exploratory level, the data on the motivation behind choice of food were obtained through the scale developed by Kim and Eves (2012) and the data on neophobic and neophilic tendencies were gathered using the scale by Pliner and Hobden (1992). This survey is face-to-face administered to the foreign tourists aged 18 and above who visited Istanbul between April 18th and May 10th, 2018 and had an experience of Turkish cuisine during their visits, using quota sampling. The data obtained from 667 surveys are analysed through descriptive statistics such as missing data analysis, multiple sling analysis, multiple normal distribution test as well as factor and regression analysis. This study concludes that the neophobic tendencies of tourists have a significant impact on the dimensions of cultural experience and sensory attraction, which are among dimensions of motivation behind choice of Turkish cuisine and that their neophilic tendencies have a significant impact on all dimensions of motivation behind choice of Turkish cuisine.
\end{abstract}

Key Words: Turkish cuisine, Neophobic tendency, Neophilic tendency, Istanbul.

Öz

Araştırma, yabancı turistlerin sergiledikleri neofobi ve neofili eğilimlerinin Türk mutfağı seçim motivasyonları üzerindeki etkisini tespit etmeyi amaçlamaktadır. Araştırmanın evrenini, 2018 yılında İstanbul'u ziyaret eden yabancı turistler oluşturmaktadır. Açımlayıcı düzeyde tasarlanan araştırmada, yiyecek seçim motivasyonlarına ilişkin veriler, Kim ve Eves (2012); neofobi ve neofili eğilimine ilişkin veriler ise Pliner ve Hobden (1992) tarafından geliştirilen ölçek aracılığıyla toplanmıştır. Söz konusu anket, 18 Nisan ile 10 Mayıs 2018 tarihleri arasında İstanbul'u ziyaret eden, ziyareti esnasında Türk mutfağı deneyimi yaşayan ve yaşları 18 ve üzeri olan yabancı turistlere kota örneklemesi temel alınarak yüz yüze uygulanmıştır. Araştırma kapsamında 667 anketin verileri analiz edilmiştir. Verilere; kayıp veri analizi, çoklu sapan analizi, çoklu normal dağılım testleri gibi tanımlayıcı istatistiklerin yanı sıra; faktör ve regresyon analizleri de uygulanmıştır. Araştırma sonucunda, neofobi eğiliminin Türk mutfağı seçim motivasyon boyutlarından olan kültürel deneyim ve duyusal çekicilik faktörleri üzerinde; turistlerin neofili eğilimlerinin ise, yiyecek seçim motivasyonlarının tüm boyutlarında anlamlı bir etkisi olduğu tespit edilmiştir.

Anahtar Kelimeler: Türk mutfağı, Neofobi eğilimi, Neofili eğilimi, İstanbul.

\footnotetext{
* Bu çalışma "Yabancı Turistlerin Türk Mutfağı Seçim Motivasyonlarının Neofobi ve Neofili Düzeylerine Göre İncelenmesi: İstanbul'da Bir Araştırma" başlıklı doktora tezinden türetilmiştir.
} 


\section{Introduction}

Motivational factors behind the choice of local food by tourists have been an important research subject due to the increased demand for local food in tourism destinations (Kodaş and Özel, 2016: 84). Motivation behind the choice of local food is defined as the reasons that lead an individual to have local food experience in a particular region/destination (Pas, 2017: 7). Studies in the literature show that tourists exhibit different motivations about the choice of local food in a specific destination and that their motivation dimensions differ (Fields, 2002; Sparks et al., 2003; Kim et al., 2010; Kim and Eves, 2012; Tao, 2012; Omar and Ab Kerim, 2014; Allan, 2016; Kim and Eves, 2016; Yusuf, 2017). Thus, it is considered that local food experience can drive or hinder an individual to choose a destination (Rızaoğlu et al., 2013: 669). Kim et al. (2009: 429) report that individuals' motivations behind their choice of local food are influenced by their neophobic and neophilic tendencies, which simply refer to an individual's tendencies regarding food. Neophobia is defined as an individual's behaviour of disliking and suspecting new and unfamiliar foodstuffs whereas neophilia is one's tendency to search for new, different and strange foods (Chang et al., 2011: 7). In this regard, neophilic tendency motivates one to travel while neophobic tendency is a dissuasive factor to travelling (Kim et al., 2010: 217) and prevents tourism behaviour (Rızaoğlu, 2012: 63). Therefore, understanding of the (neophobic/neophilic) tendencies of tourists regarding food is essential to provide new insights to practitioners into their eating habits and food choices (Rızaoğlu et al., 2013: 670). From this standpoint, this study seeks to determine the motivations of foreign tourists behind choice of Turkish cuisine and to analyse their experiences related to Turkish cuisine based on their neophobic and neophilic levels. In this regard, it examines the relationship between each variable and attempts to reveal whether their cuisine experiences are affected by neophobic or neophilic tendencies. Thus, an understanding of the relationship between the neophobic and neophilic tendencies of foreign tourists and their motivations behind choice of Turkish cuisine will offer insights for both restaurants and food and beverage businesses on motivation-based market segmentation. This study will help add new impulses to the literature in the way that it reveals the impact of the neophobic and neophilic tendencies of tourists visiting Istanbul on their motivations behind their choice of Turkish Cuisine.

\section{Conceptual Framework}

Motivation behind the choice of local food is defined as the reasons that lead an individual to have local food experience in a particular region/destination (Pas, 2017: 7). Accordingly, tourists act in the destinations they visit based on their motivation. The urge to discover new places and cultures is part of the nature of tourism movements and so is the urge to taste new and different flavours (Demirci, et al., 2015: 817). Studies on the motivations of tourists behind choice of local food in the destination they visit emphasize the dimensions of motivation such as exciting experience, escaping from routine, health concern and cultural experience (Kim et al., 2013: 484). According to Cohen (1972: 166), the travel motivation of tourists hinges on the relationship between two different motivations that grow opposite each other. The first of these motivations is the motivation to seek for novelty and strangeness whilst the second is the motivation to be afraid of and escape from unfamiliar things (cited from Rızaoğlu, 2012: 63). Fields, who theoretically study the motivations behind choice of local food, argues that individuals are affected by four factors of motivation, which are physical, cultural, interpersonal interaction and prestige and status. Physical and cultural motivations among these motivations are the factors showing whether an individual has neophobic or neophilic tendencies. Neophobic tendency refers to an individual's 
disliking unfamiliar foodstuffs and reluctance against different foodstuffs (Pliner and Hobden, 1992: 106). Şengel et al. (2015: 432) defines neophobic tendency as one's doubts about the taste, smell and appearance of unfamiliar food. People with neophobic tendencies are reluctant against new food, do not taste foodstuffs with unfamiliar ingredients and trust new food and avoid visiting ethnic restaurants as much as possible. Further, those with neophobic tendencies may find the local food in other countries strange and avoid eating any food in other cuisines during their vacation (Rızaoğlu et al., 2013: 675). On the contrary, a neophilic person tends to search for new, different and strange food. It is considerably important to experience ethnic foods in a country, meet new people and discover new and different lifestyles for those with neophilic tendencies, and these factors are an indispensable part of their travel (Yoon and Uysal, 2005: 50). It follows that the local food in a destination are considered as a barrier to travel for individuals with neophobic tendencies and also as an important attraction for tourists who seek to experience something new and to taste flavours from different cultures (Yazıcıoğlu and Alphan, 2017: 117). In this context, the increasing interest of tourists in local food in destinations has led to the question of which motivational factors tourists consider while consuming local food (Kodaş and Özel, 2016: 84). In this sense, there are many benefits to knowing the motivational factors that lead the individual to participate in tourism activities (Harman, 2012: 6). According to Demir and Kozak (2011: 19), the understanding of motivations of tourists would allow for the production and delivery of tourism products in line with the needs and desires of the consumer. These being said, although there are studies on the motivations of tourists behind choice of local food in the literature, research or data on the the motivations of foreign tourists, who visit Turkey, behind choice of local food in the Turkish cuisine are insufficient. This is the first problem statement of this study. Moreover, it is reported that neophobic and neophilic tendencies, which are individual tendencies regarding food, affect the motivational dimensions of the tourists' choice of local food and may be an attractive or unattractive factor for choice of destination of tourists. Thus, the relationship between the motivations of individuals behind choice of local food and their neophobic and neophilic tendencies in the sample of foreign tourists experiencing the Turkish cuisine, is another motivating reason for this study.

\section{Previous Research and Proposed Hypotheses}

Based on the review of the literature, it is notable that research on motivations behind choice of Turkish Cuisine/local food as well as on the relationship between neophobia and neophilia is limited in number and that this subject has been studied only by Kim et al. (2009), Hafiz et al. (2014), Selamat and Hanan (2014) and Mohd Roslan (2017).

Kim et al. (2009) performed a study with a sample of 20 people in England to identify the reasons leading individuals to consume local food and beverage in a destination. They concluded that individuals' neophobic and neophilic tendencies influence the sub-dimensions of motivation behind choice of local food. Hafiz et al. (2014) investigated whether neophobic and neophilic tendencies have an impact on consumption of local food. They collected their data from 200 tourists visiting Malaysia through surveys. The study indicated a statistically significant difference between individuals' neophilic tendencies and factors of local food consumption. It also revealed that there was no statistically significant difference between tourists' neophobic tendencies and factors of local food consumption. Selamat and Hanan (2014) performed a study in Malaysia to determine whether motivational and food-related psychological factors affect food choices of foreign tourists or not. Their data drew on surveys with 398 foreign tourists. They found out that motivational and food-related psychological factors shape the food consumption of foreign tourists in Malaysia, but 
neophobic and neophilic tendencies, which are among psychological factors, have less impact compared to motivational factors. Mohd Roslan (2017) carried out a study to ascertain the factors that affect the local food consumption of tourists during their vacation. The data were obtained from a total of 140 tourists visiting Malaysia. The study determined that tourists' neophobic and neophilic tendencies are the most important factors that affect their local food consumption. In addition to these, Bezirgan (2017) and Akyüz (2017) also explored the effect of the neophobic and neophilic tendencies of individuals on their motivation behind choice of local food. For example, Akyüz (2017: 173) concluded that neophobic tendencies have a negative impact on the motivation behind choice of local food. Dimitrovski and Crespi Vallbona (2017:21) pointed out that neophobic tendencies have a significant impact on cultural experience and escaping from routine, which are among the factors of the motivation behind choice of local food. Eertmans et al. (2005) determined that there is a significant correlation between neophobic tendencies and the dimensions of health, weight control, familiarity and ethical concern, which are related to the motivation behind choice of food. Mak et al. (2017) identified 7 dimensions regarding the motivation behind consumption of local food and demonstrated that there is a significant correlation between neophobic tendencies, and the dimensions of motivation behind choice of Turkish cuisine such as innovation and diversity, interpersonal interaction and culture, health concern and familiarity. Therefore, considering the findings of the related literature, neophobic and neophilic tendencies seem to affect the motivation behind choice of local food. In this context, this study seeks to investigate the impact of the neophobic and neophilic tendencies of tourists visiting Istanbul on their motivations behind choice of Turkish cuisine. To that end, this study tests the following hypotheses:

$\mathbf{H}_{1}$ : The neophobic tendencies of foreign tourists have a negative significant impact on their motivations behind choice of Turkish cuisine.

$\mathbf{H}_{2}$ : The neophilic tendencies of foreign tourists have a positive significant impact on their motivations behind choice of Turkish cuisine.

\section{Methodology}

This study is derived from the doctoral thesis that is entitled "Investigation of the motivation of foreign tourists to choose Turkish cuisine according to their level of neophobia and neophilia: A research in Istanbul" given to the Social Sciences Institute of Mersin University. Doctoral thesis was prepared according to the ethical rules of social sciences. The relevant ethical declaration has also been given to the institute. Quantitative research method has been applied. The data were obtained by questionnaire technique. Indeed, the research model of this study is a relational survey method due to the relationship between the motivations of foreign tourists visiting Istanbul behind choice of Turkish cuisine and their neophobic and neophilic tendencies. Based on its purpose, this study is an exploratory research. The research population consists of foreign tourists visiting Istanbul between April-May, 2018. To calculate the sample, the Istanbul Tourism Statistics Report prepared by the Istanbul Provincial Culture and Tourism Directorate (See. Table 1) was reviewed to specify the nationalities and number of tourists visiting Istanbul between April-May, 2017. The sample size was calculated based on the sampling formula $\left(n=P . Q . Z^{2} \alpha / H^{2}\right)^{1}$ used for infinite population ratio ( $\mathrm{N}>10.000)$ (Ural and Kılıç, 2006, p. 47). The calculation was made based on the ratio that maximizes the variance $(p=0,50)$ and on $5 \%$ 
significance level and $4 \%$ margin of random error, and the sample size was determined to be 600 .

$$
{ }^{1} n=. P \cdot Q \cdot Z^{2} \alpha / H^{2}=0,5^{*} 0,5^{*} 1,96^{2} / 0,04^{2}=600 .
$$

Given that it is not possible to obtain a complete list of innumerable foreign tourists visiting Istanbul, quota sampling, which is a non-probability sampling method, was used in this study; tourists in the top 10 nationalities were identified. The data were collected from these tourists face-to-face in line with convenience sampling method, using a survey developed based on the literature. The data on motivations behind choice of food in this study drew on the survey developed by Kim and Eves (2012) and the data on neophobic and neophilic tendencies in this study drew on the survey developed by Pliner \& Hobden (1992). Originally written in English, these survey forms consist of 31 statements on motivations behind choice of food, and each of them have 5 statements on neophobic and neophilic tendencies. The participants answered on the items in the survey considering the 7-point Likert type format. In the study, the pre-test was applied to foreign tourists who walked around Istanbul Sultan Ahmet on the street and (who) volunteered to participate in the study in April 2018. The data of the pilot study were collected from a total of 54 foreign tourists and the questions considered to be unclear or difficult to understand were reviewed and refined.

Table 1 shows the quotas distributed prior to the administration of the survey and the number of surveys completed during the study.

Table 1: Table for foreign tourist quota based on variable of nationality

\begin{tabular}{|c|c|c|c|c|c|c|}
\hline $\begin{array}{c}\text { Row } \\
\text { No }\end{array}$ & Country & $\begin{array}{c}\text { Number of } \\
\text { visitors }\end{array}$ & Percentage & Quota & $\begin{array}{c}\text { Number of } \\
\text { surveys } \\
\text { completed }\end{array}$ & Deviation \\
\hline 1 & Germany & 154.154 & 0,196 & 118 & 94 & -24 \\
\hline 2 & Iran & 109,967 & 0,179 & 107 & 112 & +5 \\
\hline 3 & Russia & 81,074 & 0,111 & 66 & 76 & +10 \\
\hline 4 & Saudi Arabia & 79,455 & 0,103 & 62 & 85 & +23 \\
\hline 5 & Iraq & 65,016 & 0,098 & 59 & 76 & +17 \\
\hline 6 & England & 59,918 & 0,076 & 45 & 54 & +9 \\
\hline 7 & France & 58,766 & 0,074 & 44 & 55 & +11 \\
\hline 8 & Ukraine & 54,164 & 0,060 & 36 & 41 & +5 \\
\hline 9 & United States & 46,760 & 0,054 & 32 & 43 & +11 \\
\hline 10 & Netherlands & 43,010 & 0,050 & 30 & 40 & +10 \\
\hline & & 752.284 & 1,000 & 600 & 676 & 76 \\
\hline
\end{tabular}

${ }^{1} \mathrm{n}$ :Sample size; P: Probability of occurrence of event in population; Q: Probability of non-occurrence of event in population(1-P); Z: Theoretical value corresponding to a certain level of significance - $Z$ value for $\alpha: 0,05$ is 1,$96 ; H$ : Standard error value /sampling error. 
Table 1 demonstrates that the quotas distributed prior to the study were exceeded in all countries except Germany. Although the quota distributed for Germany was 118 , only 94 surveys were conducted, which implies that about $20.5 \%$ of the quota was not filled. Despite this, the targeted 600 surveys in total were exceeded by $12.6 \%$. Thus, a total of 676 tourists from 10 different countries completed the surveys. The Central Limit Theorem (CLT) assumes that when the size of the sample exceeds 30 , the average of the sample will be close to the normal distribution. 667 questionnaires in total were collected during the survey period; thus, it was considered that the data were normally distributed according to the CLT. Following this, each survey was analysed for its completeness, accuracy and consistency. All items in the scale were answered; and according to multiple sling analysis, a total of 9 observations were excluded from the data set. As a result, the analysis was performed on 667 surveys. The data were analysed through frequency distributions and rates, as well as average and missing data analysis, multiple sling analysis, multiple normal distribution test, factor and regression analysis.

The reliability of the scale for the motivation of foreign tourists behind their choice of Turkish cuisine was tested and the reliability coefficient (Cronbach's Alpha) value of the scale was determined to be 0.923 . The reliability of the neophobia scale used in this study was tested and its Alpha coefficient was found as 0.805 whereas the Cronbach's Alpha value of the neophilia scale was determined to be 0.825 . To test the construct validity of the motivation of foreign tourists behind their choice of Turkish cuisine, the scale was examined through factor analysis. Lastly, the factor analysis performed on the scale for motivation behind choice of Turkish cuisine identified 6 factors for the 25-item scale. The resulting dimensions are cultural experience, sensory attraction, health concern, excitement, togetherness and earning respect. The factor analysis conducted for the neophobic and neophilic scale showed that the scales consisted of one dimension.

\section{Findings}

Table 2 demonstrates findings on the demographic characteristics of a total of 667 foreign tourists participating in the study. Accordingly, $37.5 \%$ of the tourists were aged between $26-33$, and $53.5 \%$ of them $(n=358)$ were female tourists.

Table 2: Distribution of the participants by demographic characteristics

\begin{tabular}{|l|l|l|l|l|l|}
\hline Characteristic & Frequency & Percentage & Characteristic & Frequency & Percentage \\
\hline \multicolumn{3}{|l}{ Age } & & Nationality & \\
\cline { 4 - 7 } & & Iran & 112 & 16,8 \\
\hline Aged 18-25 & 192 & 28,8 & Germany & 94 & 14,1 \\
\hline Aged 26-33 & 250 & 37,5 & Saudi Arabia & 85 & 12,7 \\
\hline Aged 34-41 & 118 & 17,7 & Iraq & 76 & 11,4 \\
\hline $\begin{array}{l}\text { Aged 42 or } \\
\text { older }\end{array}$ & 107 & 16,0 & Russia & 76 & 11,4 \\
\hline Total & & 100,0 & France & 55 & 8,2 \\
\hline \multirow{2}{*}{ Gender } & 667 & England & 54 & 8,1 \\
\cline { 4 - 7 } & & $\begin{array}{l}\text { The United } \\
\text { States }\end{array}$ & 43 & 6,4 \\
\hline Female & 357 & 53,5 & Netherlands & 40 & 6,0 \\
\hline Male & 310 & 46,5 & Ukraine & 32 & 4,8 \\
\hline Total & 667 & 100,0 & Total & 667 & 100,0 \\
\hline
\end{tabular}


As seen in Table 2, $16.8 \%$ of the participants were Iranian; $14.1 \%$ of them were German and $12.7 \%$ were Saudi Arabian. The smallest number of participants respectively came from the United States $(6.4 \%)$, Netherlands $(6.0 \%)$ and Ukraine $(4.8 \%)$.

The first hypothesis of this study is that "The neophobic tendencies of foreign tourists have a negative significant impact on their motivations behind choice of Turkish cuisine." To test this hypothesis, a simple linear regression analysis was performed. The reason is that each dimension of the motivation behind choice of Turkish cuisine was considered as dependent variable and neophobic tendency was treated as independent variable. The dimension of cultural experience of motivation behind choice of Turkish cuisine was considered as dependent variable in the first simple regression analysis performed to investigate the impact of the neophobic tendencies of foreign tourists on motivation behind their choice of Turkish cuisine; neophobic tendency was treated as independent variable. Table 3 outlines the results of the simple regression analysis.

Table 3: Results of the simple regression analysis on the impact of neophobic tendency on the dimensions of motivation behind choice of Turkish cuisine

\begin{tabular}{|c|c|c|c|c|c|}
\hline \multirow{2}{*}{\begin{tabular}{|l} 
\\
Models
\end{tabular}} & \multicolumn{2}{|c|}{$\begin{array}{l}\text { Unstandardized } \\
\text { Coefficients }\end{array}$} & \multirow{2}{*}{$\begin{array}{c}\begin{array}{c}\text { Standardized } \\
\text { Coefficients }\end{array} \\
\beta\end{array}$} & \multirow{2}{*}{$\begin{array}{c}\mathrm{t} \\
\text { value }\end{array}$} & \multirow{2}{*}{$\begin{array}{l}\text { Significance } \\
\text { level }\end{array}$} \\
\hline & $\beta$ & Std.Error & & & \\
\hline (Constant) & 6,199 & ,099 & & 62,519 & ,000 \\
\hline Neophobic tendency & $-0,16$ & ,022 & -028 &,- 723 & ,470 \\
\hline \multicolumn{6}{|c|}{$\begin{array}{l}\text { Dependent variable: The dimension of cultural experience } \\
R: 0,028 ; R^{2}: 0,001 ; \text { Adjusted } R^{2}:-0,001 ; F: 0,523, p<0,001\end{array}$} \\
\hline (Constant) & 6,606 & ,107 & & 61,668 &, 000 \\
\hline Neophobic tendency &,- 105 & ,023 &,- 171 & $-4,486$ & ,000 \\
\hline \multicolumn{6}{|c|}{$\begin{array}{l}\text { Dependent variable: The dimension of sensory attraction } \\
R: 0,171 ; R^{2}: 0,029 ; \text { Adjusted } R^{2}: 0,028 ; F: 20,125, p<0,001\end{array}$} \\
\hline (Constant) & 5,812 & ,126 & & 46,232 &, 000 \\
\hline Neophobic tendency &,- 121 & ,027 &,- 168 & $-4,402$ &, 000 \\
\hline \multicolumn{6}{|c|}{$\begin{array}{c}\text { Dependent variable: The dimension of health concern } \\
\text { R: } 0,168 ; R^{2}: 0,028 ; \text { Adjusted } R^{2}: 0,027 ; F: 19,377, p<0,001 ; D-W: 1,664\end{array}$} \\
\hline (Constant) & 5,704 &, 115 & & 49,517 &, 000 \\
\hline Neophobic tendency &, 013 & ,025 & ,019 & ,498 & ,619 \\
\hline \multicolumn{6}{|c|}{$\begin{array}{l}\text { Dependent variable: The dimension of excitement } \\
\mathrm{R}: 0,019 ; \mathrm{R}^{2}: 0,000 ; \text { Adjusted } \mathrm{R}^{2}:-0,001 ; \mathrm{F}: 0,248, \mathrm{p}<0,001\end{array}$} \\
\hline (Constant) & 6,063 &, 110 & & 55,301 &, 000 \\
\hline Neophobic tendency &,- 052 & ,024 &,- 084 & $-2,163$ & ,031 \\
\hline \multicolumn{6}{|c|}{$\begin{array}{l}\text { Dependent variable: The dimension of togetherness } \\
\text { R: } 0,084 ; R^{2}: 0,007 ; \text { Adjusted } R^{2}: 0,005 ; F: 4,680, p<0,001 ; D-W: 1,807\end{array}$} \\
\hline (Constant) & 5,504 & 153 & & 39,915 &, 000 \\
\hline Neophobic tendency &,- 016 & ,033 &,- 019 &,- 478 & ,633 \\
\hline \multicolumn{6}{|c|}{$\begin{array}{l}\text { Dependent variable: The dimension of earning respect } \\
\text { R: } 0,019 ; R^{2}: 0,000 ; \text { Adjusted } R^{2}:-0,001 ; F: 0,228, p<0,001\end{array}$} \\
\hline
\end{tabular}

As seen in Table 3, the neophobic tendencies of tourists do not have a significant impact on the dimensions of cultural experience, excitement and earning respect among the dimensions of motivation behind choice of Turkish cuisine. On the 
other hand, neophobic tendency has a significant impact on the dimensions of sensory attraction, health concern and togetherness. The results of the regression analysis where neophobic tendency was treated as independent variable and the dimension of sensory attraction was considered as dependent, show that the model is significant $(F=20,125 ; p<0,01)$. Also, t-statistic, which determines the significance of regression coefficients, is significant $(t=-4,486 ; p<0,05)$. There is a negative correlation $(R=-0,171)$ between the variables. The $R^{2}$ value, which indicates how much of dependent variable is explained by independent variable, was calculated as 0,029 . This result means that $2.9 \%$ of the variation in the dimension of sensory attraction was explained by the variation in neophobic tendencies. A 1-unit increase in neophobia tendency reduces the dimension of sensory attraction by a 0.171 unit. Table 3 shows that there is a negative correlation $(R=-0,168)$ between the dimension of health concern, which is one of the dimensions of motivation behind choice of Turkish cuisine, and neophobic tendencies in another regression model that yielded significant results. The $\mathrm{R}^{2}$ value, which indicates how much of dependent variable is explained by independent variable, was calculated as 0,028 . This result means that $2.8 \%$ of the variation in the dimension of sensory attraction was explained by the variation in neophobic tendencies. A 1-unit increase in neophobic tendency reduces the dimension of health concern by a 0.168 unit. The correlation between neophobic tendency and the dimension of togetherness, which is one of the dimensions of motivation behind choice of Turkish cuisine, is statistically significant $(p<0,05)$.

The second hypothesis of this study is that "The neophilic tendencies of foreign tourists have a positive significant impact on their motivations behind choice of Turkish cuisine." Each dimension of the motivation behind choice of Turkish cuisine was individually considered as dependent variable and neophilic tendency was treated as independent variable. To test the linear relationship between the variables, a simple linear regression analysis was conducted in order to investigate how much of the variation in the dimensions of motivation can be explained by neophilic tendency. Table 4 outlines the results of the regression analysis. The findings of the test where each dimension of the motivation behind choice of Turkish cuisine was individually considered as dependent variable and neophilic tendency was treated as independent variable show that each model is significant and there is a positive correlation between the variables. Table 4 demonstrates that the model established between neophilia and the dimension of cultural experience $(F=169,377 ; p<0,05)$ is statistically significant. The $R$ value of 0,451 points to positive correlation between the variables. The $R^{2}$ value is 0,203 . This result means that $20.3 \%$ of the variation in the dimension of cultural experience was explained by the variation in neophilic tendencies. A 1-unit increase in neophilic tendency reduces the dimension of cultural experience by a 0.451 unit. The impact of neophilic tendency on the dimension of sensory attraction was found to be statistically significant $(F=71,844 ; p<0,05)$. The $R$ value of 0,312 points to positive correlation between the variables. The $\mathrm{R}^{2}$ value is 0,098 . This result means that $9.8 \%$ of the variation in the dimension of sensory attraction was shaped by the variation in neophilic tendencies as independent variable. A 1-unit increase in neophilic tendency reduces the dimension of sensory attraction by a 0.312 unit. 
Table 4: Results of the simple regression analysis on the impact of neophilic tendency on the dimensions of motivation behind choice of Turkish cuisine

\begin{tabular}{|c|c|c|c|c|c|}
\hline \multirow[b]{2}{*}{ Models } & \multicolumn{2}{|c|}{$\begin{array}{l}\text { Unstandardized } \\
\text { Coefficients }\end{array}$} & \multirow{2}{*}{$\begin{array}{c}\begin{array}{c}\text { Standardized } \\
\text { Coefficients }\end{array} \\
\beta \\
\end{array}$} & \multirow{2}{*}{$\begin{array}{c}\mathbf{t} \\
\text { value }\end{array}$} & \multirow{2}{*}{$\begin{array}{c}\text { Significance } \\
\text { level }\end{array}$} \\
\hline & $\beta$ & Std.Error & & & \\
\hline (Constant) & 3,875 & ,176 & & 22,039 & ,000 \\
\hline Neophilic tendency & ,386 & ,30 & ,451 & 13,014 & ,000 \\
\hline \multicolumn{6}{|c|}{$\begin{array}{l}\text { Dependent variable: The dimension of cultural experience } \\
\text { R: } 0,451 ; R^{2}: 0,203 ; \text { Adjusted } R^{2}: 0,202 ; F: 169,377, p<0,001\end{array}$} \\
\hline (Constant) & 4,439 & ,205 & & 21,642 &, 000 \\
\hline Neophilic tendency & ,293 & ,035 & ,312 & 8,476 & ,000 \\
\hline \multicolumn{6}{|c|}{$\begin{array}{l}\text { Dependent variable: The dimension of sensory attraction } \\
\mathrm{R}: 0,312 ; \mathrm{R}^{2}: 0,098 ; \text { Adjusted } \mathrm{R}^{2}: 0,096 ; \mathrm{F}: 71,844, \mathrm{p}<0,001\end{array}$} \\
\hline (Constant) & 4,166 & ,249 & & 16,708 &, 000 \\
\hline Neophilic tendency & ,192 & ,042 & , 175 & 4,573 & ,000 \\
\hline \multicolumn{6}{|c|}{$\begin{array}{l}\text { Dependent variable: The dimension of health concern } \\
\mathrm{R}: 0,175 ; \mathrm{R}^{2}: 0,030 ; \text { Adjusted } \mathrm{R}^{2}: 0,029 ; \mathrm{F}: 20,913, \mathrm{p}<0,001\end{array}$} \\
\hline (Constant) & 3,424 & ,210 & & 16,341 &, 000 \\
\hline Neophilic tendency & ,399 & ,035 & ,401 & 11,298 & ,000 \\
\hline \multicolumn{6}{|c|}{$\begin{array}{c}\text { Dependent variable: The dimension of excitement } \\
\mathrm{R}: 0,401 ; \mathrm{R}^{2}: 0,161 ; \text { Adjusted } \mathrm{R}^{2}: 0,160 ; \mathrm{F}: 127,637, \mathrm{p}<0,001\end{array}$} \\
\hline (Constant) & 3,706 & ,202 & & 18,375 & ,000 \\
\hline Neophilic tendency & ,365 & ,034 & ,384 & 10,726 &, 000 \\
\hline \multicolumn{6}{|c|}{$\begin{array}{c}\text { Dependent variable: The dimension of togetherness } \\
\mathrm{R}: 0,384 ; \mathrm{R}^{2}: 0,147 ; \text { Adjusted } \mathrm{R}^{2}: 0,146 ; \mathrm{F}: 115,039, \mathrm{p}<0,001\end{array}$} \\
\hline (Constant) & 3,949 & ,299 & & 13,220 & ,000 \\
\hline Neophilic tendency & ,254 & ,050 & , 192 & 5,047 & ,000 \\
\hline \multicolumn{6}{|c|}{$\begin{array}{c}\text { Dependent variable: The dimension of earning respect } \\
R: 0,192 ; R^{2}: 0,037 ; \text { Adjusted } R^{2}: 0,035 ; F: 25,476, p<0,001\end{array}$} \\
\hline
\end{tabular}

Another significant result in Table 4 is the positive correlation between the dimension of togetherness, which is one of the dimensions of motivation behind choice of Turkish cuisine, and neophilic tendencies. The $R^{2}$ value is 0,147 . This result means that $14.7 \%$ of the variation in the dimension of excitement was explained by the variation in neophilic tendencies. A 1-unit increase in neophilic tendency reduces the dimension of sensory attraction by a 0.384 unit. Further, the impact of neophilic tendency on the dimension of excitement $(F=127,637 ; p<0001)$ and on the dimension of health concern $(F=20,913 ; p<0001)$ was found to be statistically significant. Consequently, the impact of neophilic tendencies on all dimensions of motivation behind choice of Turkish cuisine was positive and significant.

\section{Conclusion and Suggestions}

This study seeks to determine the impact of the neophobic and neophilic tendencies of foreign tourists on motivations behind their choice of Turkish cuisine. To that end, it tests the impact of the neophobic tendencies of foreign tourists on motivations behind their choice of Turkish cuisine; the results show that the impact of the neophobic 
tendencies on the dimensions of cultural experience, excitement and earning respect, which are among the dimensions of motivations behind their choice of Turkish cuisine, is not significant. Hafiz et al. (2014) asserted that neophobic tendency does not have a significant impact on factors of local food consumption. Thus, the findings of this study are congruent with those in the literature. On the other hand, neophobic tendencies have a negative and significant impact on the dimensions of sensory attraction, health concern and togetherness. This may result from the fact that the foreign tourists participating in this study dislike the sensory properties of Turkish cuisine such as the smell and appearance of local food, that individuals with health concerns do not think that these food are fresh or nutritious, or that tasting local food in Turkish cuisine is not seen as a special experience by tourists. In the literature, Akyüz (2017), Kim et al. (2009) found out that neophobic tendency has a significant effect on the dimensions of sensory attraction and health concern. Metz (2014) determined a significant correlation between the motivational dimensions of food and neophobic tendencies, one of the food-related personality characteristics, which supports the findings of this present study. Also, Selamat and Hanan (2014), Mohd Roslan (2017) pointed to the significant impact of neophobic tendencies on the motivation behind choice of local food. These being said, the findings of this study are consistent with the findings in the current literature.

In conclusion, this study shows that the impact of the neophobic tendencies of foreign tourists on each dimension of motivations behind their choice of Turkish cuisine is positive and significant. This is congruent with the finding of Dimitrovski and Crespi Vallbona (2017) that there is a positive significant correlation between one's neophilic tendencies and the dimension of cultural experience, which is one of the factors for motivations behind choice of local food. Mak et al. (2012) reported the significant impact of neophilic tendencies on the motivation behind choice of local food. The dimensions of cultural experience $(\beta=0,451)$ and excitement $(\beta=0,401)$ are the dimensions of motivation most valued by tourists with neophilic tendencies. This implies that tourists look for local food experience to enhance their knowledge about different cultures, to discover new things, to see things that they do not see in their normal life and to discover the taste of local food. Besides, there are various studies in the literature supporting the argument that tasting local food is an exciting experience (Sparks et al., 2003; Kim et al., 2009). It follows that tourists always prefer visiting places where they can have extraordinary food experiences that require more courage, rather than their usual experiences. The dimension of health concern $(\beta=0,175)$ is the motivation dimension less valued by tourists with neophilic tendencies compared to other dimensions. This finding is congruent with the results of Alphan (2017). That said, the second hypothesis formulated in this study is accepted and the first hypothesis is partially accepted. The reason why the first hypothesis is partially accepted is that the significant difference of neophobia levels of foreign tourists on the dimensions of motivation behind choice of Turkish cuisine is only found in the dimensions of cultural experience, excitement and earning respect.

With a focus on foreign tourists, this present study has analysed the impact of neophobic and neophilic tendencies on the motivation behind their choice of Turkish cuisine. Understanding of the relationship between the neophobic and neophilic tendencies of foreign tourists and their motivations behind their choice of Turkish Cuisine provides better insights into the type of tendency that has an influence on the foreign tourists with different motivations, neophobic and neophilic tendencies, and helps developing marketing mix strategies appropriate for this particular type of tendency. The fact that the neophobic tendencies of tourists negatively affect their consumption of local food has an important role to play in the decision making process 
regarding the range of products to be offered at destinations. In light of these, certain suggestions can be offered for further studies. A study similar to the present one, which was performed with tourists from 10 different countries, can be conducted with different groups of tourists or local tourists. An understanding of the tendencies of individuals from more nationalities will allow for a more extensive overview and a better comparison of the differences and similarities. This study also suggests food and beverage managers, marketing professionals and relevant stakeholders to encourage tourists to consume local food during their holidays based on the findings presented here on motivation and neophobic/neophilic tendencies. Further studies might concentrate on different tendencies (such as search for diversity and food involvement) with a potential impact on the motivation behind choice of Turkish cuisine; in this way, it will be possible to compare the tendencies that affect the motivations of foreign tourists behind their choice of Turkish cuisine.

\section{References}

Allan, M. (2016). 'Exploring the relationship between local food consumption and intentional loyalty'. Journal of Tourism-Studies and Research in Tourism, 21, pp. 33-38.

Alphan, E. (2017). A Study on Factors Affecting Local Food Consumption in Tourism Destinations. Master's thesis, Gazi University, The Institute of Social Sciences, Ankara.

Akyüz, B. G. (2017). Culinary Tourism: Factors that Influence Local Food Consumption Motivation and Their Effects on Travel Intentions. Doctoral thesis, Bahçeşehir University, The Institute of Social Sciences, Istanbul.

Bezirgan, M. (2017). 'Mediation Effect of Food Attitude Between Food Neobhobia and Destination Attachment: A Survey on Japanese Tourist Who Visited Turkey'. In R. Efe et al. (Eds.), Developments in Social Sciences (pp. 583-593). Sofia: St. Kliment Ohridski University Press.

Chang, R. C., Kivela, J. and Mak, A. H. (2011). 'Attributes that influence the evaluation of travel dining experience: When east meets west'. Tourism Management, 32 (2), pp. 1-38.

Cohen, E. (1972). 'Toward a Socıology of International Tourism'. Social Research, 39, pp. 164-182.

Demir Ş. Ş. and Kozak M. (2011). 'An investigation of the relationship between stages of consumer behaviors model in tourism'. Anatolia: A Journal of Tourism Research, 22 (1), pp. 19-34.

Demirci, B., Timur, B., Yılmazdoğan, C. and Oğuz, Y. E. (2015). The effect of domestic tourists' local food consumption motivation on future intention: The case of Eskişehir. I. International Turkish World Tourism Symposium, 19-21 November, Kastamonu, pp. 816-826.

Dimitrovski, D. and Crespi-Vallbona, M. (2017). 'Role of food neophilia in food market tourists' motivational construct: The case of La Boqueria in Barcelona, Spain'. Journal of Travel and Tourism Marketing, 34 (4), pp. 75-487.

Eertmans, A., Victoir, A., Vansant, G. and Bergh, Ö. V. (2005). 'Food-related personality traits, food choice motives and food intake: Mediator and moderator relationships'. Food Quality and Preference, 16, pp. 714-726

Fields, K. (2002). 'Demand for the gastronomy tourism product: Motivational factors'. In A. M. Hjalager and G. Richards (Eds.), Tourism and gastronomy (pp. 36-50). London: Routledge.

Hafiz, M. N. M., Zainal, A., Ahmad Nizan, Z. and Shahariah, I. (2014). 'The influence of food neophilia and neophobia towards tourists comsumption of Malay food in Malaysia'. In N. Sumarjan, M. S. M. Zahari, S. M. Radzi \& et al. (Eds.), 
Hospitality and tourism: Synergizing creativity and Innovation in research (pp. 223-227), London: CRC Press.

Harman, S. (2012). Backpackers' travel motivations and involvement: A research on backpackers visiting Istanbul. Doctoral thesis, Çanakkale Onsekiz Mart University, The Institute of Social Sciences, Çanakkale.

Kim, Y. G. and Eves, A. (2012). 'Construction and validation of a scale to measure tourist motivation to consume local food'. Tourism Management, 33 (6), pp. 1458-1467.

Kim, Y. G. and Eves, A. (2016). 'Measurement equivalence of an Instrument measuring motivation to consume local food: A cross-cultural examination across British and Korean'. Journal of Hospitality and Tourism Research, 40 (5), pp. 634-652.

Kim, Y. G., Eves, A. and Scarles, C. (2009). 'Building a model of local food consumption on trips and holidays: A grounded theory approach'. International Journal of Hospitality Management, 28 (3), pp. 423-431.

Kim, Y. G., Eves, A. and Scarles, C. (2013). 'Empirical verification of a conceptual model of local food consumption at a tourist destination'. International Journal of Hospitality Management, 33, pp. 484-489.

Kim, Y. H., Goh, B. K. and Yuan, J. J. (2010). 'Development of a multi-dimensional scale for measuring food tourist motivations'. Journal of Quality Assurance in Hospitality and Tourism, 11 (1), pp. 56-71.

Kim, Y. H., Suh, B. W. and Eves, A. (2010). 'The relationships between food-related personality traits, satisfaction, and loyalty among visitors attending food events and festivals'. International Journal of Hospitality Management, 29 (2), pp. 216226.

Kodaş, D. and Özel, Ç. H. (2016). 'Determing the domestic visitors motivations of local food comsumption: Case of Beypazarı'. Aksaray University Faculty of Economics and Administrative Sciences Journal, 8 (1), pp. 83-96.

Mak, A. H., Lumbers, M., Eves, A. and Chang, R. C. (2012). 'Factors influencing tourist food consumption'. International Journal of Hospitality Management, 31 (3), pp. 928-936.

Mak, A. H. N., Lumbers, M., Eves, A. and Chang, R. C. Y. (2017). 'The effects of foodrelated personality traits on tourist food consumption motivations'. Asia Pacific Journal of Tourism Research, 22 (1), pp. 1-20.

Metz, J. (2014). Personality traits and food choice motives. Explaining the intention of choosing organic products in restaurants. Master thesis, Wageningen University, Holland.

Mohd Roslan, N. S. (2017). 'The role of motivational and physiological factors in food tourism: Evidence from Malaysia'. Journal of Hospitality and Networks, 1 (1), pp. 1-24.

Omar, S. R. and Ab Karim, M. S. (2014). 'Factors attracting Malaysian heritage food (HF) comsumption amongst international tourists in Malaysia'. In N. Sumarjan, M. S. M. Zahari, S. M. Radzi \& et al. (Eds.), Hospitality and tourism: synergizing creativity and Innovation in research (pp. 253-258). London: CRC Press.

Pas, L. V. D. (2017). Dutch consumers' willingness to try insects: The influence of food choice motives on intentions. Master's thesis, Wageningen University and Research, Netherlands.

Pliner, P. L. and Hobden, K. (1992). 'Development of a scale to measure the trait of foodneophobia in humans'. Appetite, 19 (2), pp. 105-120.

Rızaoğlu, B. (2012). Tourism Behaviour. Ankara: Detay Publishing.

Rızaoğlu, B., Ayazlar, R. A. and Gençer, K. (2013). 'Evaluation of individual trends related to food experience in terms of socio-demographic characteristics: Case 
of foreign tourists visiting Kuşadası'. 14 $4^{\text {th }}$ National Tourism Congress, 5-8 December, Kayseri, pp. 669-687.

Selamat, H. and Hanan, F. A. (2014). 'Factors influencing international tourists' food preference towards Malaysian local food'. In N. Sumarjan et al. (Eds.), Hospitality and tourism: Synergizing creativity and Innovation in research (pp. 303-308). London: CRC Press,

Sparks, B., Bowen, J. and Klag, S. (2003). 'Restaurant and the tourist market. International Journal of Contemporary Hospitality Management', 15 (1), pp. 6-13.

Şengel, T., Karagöz, A., Çetin, G., İstanbullu Dinçer, F., Ertuğral, S. M. and Balık, M. (2015). 'Tourists' aproach to local food'. Procedia-Social and Behavioral Sciences, 195, pp. 429-437.

Tao, Z. (2012). 'A study on the effect of food tourism motivation on tourist satisfaction and behavioral intention'. Tourism Tribune/Lvyou Xuekan, 27 (10), pp. 78-84.

Ural, A. and Kılıç, İ. (2006). Scientific research process and data analysis with SPSS. Ankara: Detay Publishing.

Yazıcıoğlu, İ. and Alphan, E. (2017). 'Analysis of factors affecting local food-beverage comsumption in tourist destinations'. 4th International Congress of Tourism \& Management Researches, 12-14 May, Gyraine/Northern Cyprus, pp. 116-129.

Yoon, Y. and Uysal, M. (2005). 'An examination of the effects of motivation and satisfaction on destination loyalty: A structural model'. Tourism Management, 26 (1), pp. 45-56.

Yusuf, M. (2017). 'Measuring tourist's motivations for consuming local Angkringan street food in Yogyakarta, Indonesia'. Journal of Indonesian Tourism and Development Studies, 5 (2), pp. 6572. 